randomized controlled trials incorporating risk and treatment factors (dose, class, course length, hydrophilicity) are necessary [4]. In conclusion, given the global disease burden and grave implications of advanced AMD, novel treatment with statins deserves further study and consideration.

Funding This work was supported by a Medical Scholars Grant, a medical student research grant awarded from the School of Medicine at Stanford University.

\section{Compliance with ethical standards}

Conflict of interest The authors declare that they have no conflict of interest.

\section{References}

1. Gehlbach P, Li T, Hatef E. Statins for age-related macular degeneration. Cochrane Database Syst Rev. 2015;2:CD006927.
2. Age-Related Eye Disease Study Research Group A-REDSR. A randomized, placebo-controlled, clinical trial of high-dose supplementation with vitamins $\mathrm{C}$ and $\mathrm{E}$, beta carotene, and zinc for agerelated macular degeneration and vision loss: AREDS report no. 8. Arch Ophthalmol. 2001;119:1417-36.

3. Maguire MG, Ying G, McCannel CA, Liu C, Dai Y, Complications of Age-Related Macular Degeneration Prevention Trial (CAPT) Research Group. Statin use and the incidence of advanced agerelated macular degeneration in the complications of age-related macular degeneration prevention trial. Ophthalmology. 2009;116:2381-5.

4. Vavvas DG, Daniels AB, Kapsala ZG, Goldfarb JW, Ganotakis E, Loewenstein JI, et al. Regression of some high-risk features of agerelated macular degeneration (AMD) in patients receiving intensive statin treatment. EBioMedicine. 2016;5:198-203.

5. Wenick AS, Bressler NM, Bressler SB. Age-related macular degeneration: non-neovascular early AMD, intermediate AMD, and geographic atrophy. In: Schachat AP, Wilkinson CP, Hinton DR, Sadda SR, Wiedemann P, editors. Ryan's retina. 6th ed. Philadelphia, PA: Elsevier, 2018. Chapter 68.

\title{
Van gogh and the obsession of yellow: style or side effect
}

\author{
Doğaç Demir ${ }^{1}$ · Şefik Görkey²
}

Received: 14 January 2018 / Revised: 19 July 2018 / Accepted: 7 August 2018 / Published online: 7 September 2018

(c) The Royal College of Ophthalmologists 2018

Vincent Van Gogh is well known for his yellow addiction, which might be related to a health condition [1]. There are several theories about his possible diseases, including epilepsy, Meniere's disease, and acute intermittent porphyria [2-6].

This yellow obsession makes professionals wonder: were those only reflection of his mind or how he saw the world?

There are different theories around this however, this hypothesis will focus on one theory: Xanthopsia. Xanthopsia is a rare condition that causes yellow vision which can also occur due to medications. Digitalis rarely causes

Doğaç Demir

dogacdemir@gmail.com

Marmara University, School of Medicine, İstanbul, Turkey

2 Medical History and Ethics Department, Marmara University, School of Medicine, İstanbul, Turkey yellow vision following bilirubin deposition in the eye which possibly explains his yellow addiction according to some specialists [7-9]. It is well known that he was treated by the famous physician Paul Gachet during the 19th century (Fig. 1). During that time foxglove plant, which is the main ingredient of digitalis, was used for the treatment of epilepsy and mania [2, 10-13].

Although, we don't have the medical recordings of him, it is possible that Gachet used digoxin on him considering Gogh painted him several times with foxglove plants $[2,14,15]$.

Moreover, the yellow color dominates his paintings he painted during his hospital stay.

Although there are several reasons to consider this yellow love is not natural, the opposite seems more reliable because of several reasons.

First, his treatment under Gachet lasted only 2 months. Studies suggest 2 months are not enough for the development of xanthopsia [16]. 


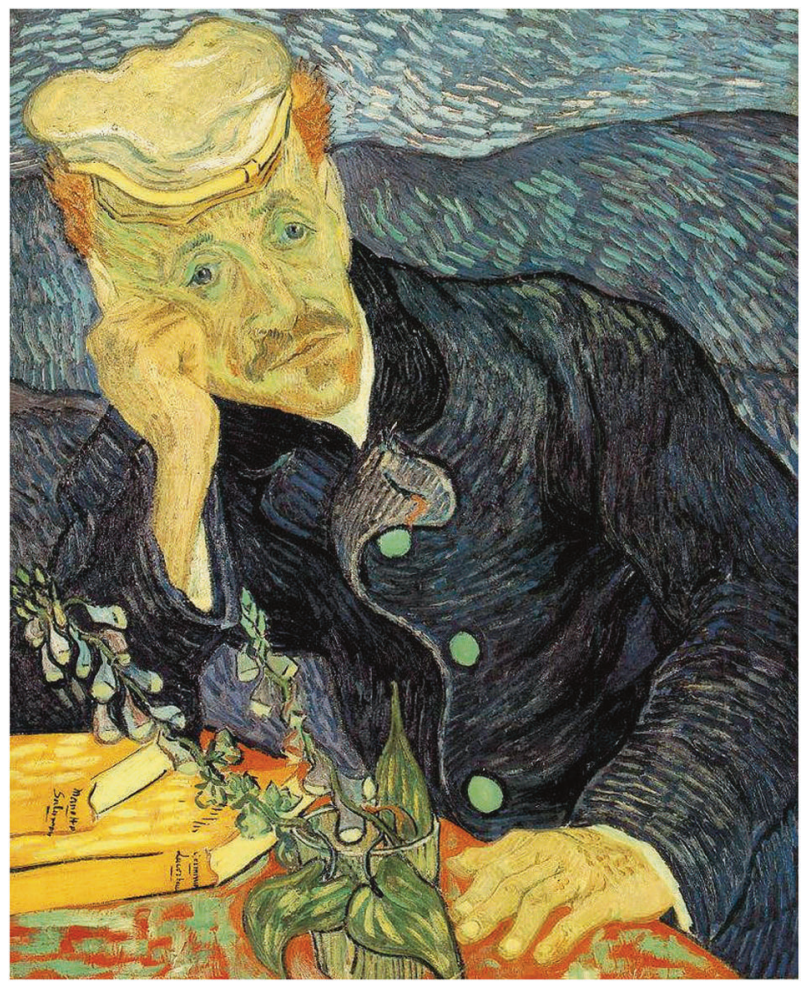

Fig. 1 Portrait of Dr. Paul Gachet

Second, Gachet was known for his careful drug usage and even wrote a scientific paper about digoxin dosage.

Finally, he was painting dominantly yellow for nearly all his artistic life, even though he was not using digitalis $[14,17,18]$.

In conclusion, it is obvious that Van Gogh suffered from some serious health problems. But multiple different reasons make it unlikely that the artist has suffered from xanthopsia.

\section{Compliance with ethical standards}

Conflict of interest The authors declare that they have no conflict of interest.

\section{References}

1. Gruener A. Vincent van Gogh's yellow vision. Br J Gen Pract. 2013;63:370-1.

2. Lee TC. Van Gogh's Vision Digitalis Intoxication? JAMA. 1981;245:727-9.

3. Arenberg IK, et al. Van Gogh had Meniere's Disease and Not Epilepsy. JAMA. 1990;264:491-3.

4. Erbay Mutlu, Van Gogh' S. Unknown Illness and the Natural Medicines Used to Treat It. T Klin Tıp Etiği Hukuku Tar. 2003;11:258-62.

5. Loftus LS, Arnold WN. Vincent van Gogh's illness: acute intermittent porphyria? BMJ. 1991;303:1589-91.

6. https://www.britannica.com/biography/Vincent-van-Gogh (accessed: 10.10 .2016$)$

7. Van Gogh, Vincent. Leo Jansen; Hans Luijten; Nienke Bakker, eds. Vincent van Gogh - The Letters. 2009

8. http://www.aaopt.org/xanthopsia (accessed: 17.05.2017)

9. http://emedicine.medscape.com/article/154336-clinical (accessed: 17.05.2017)

10. Van Gogh (İstanbul: Yapı Kredi Yayınları,2015)

11. http://psych.ucalgary.ca/PACE/VA-Lab/AVDE-Website/va ngogh.html (accessed: 10.10.2016)

12. Ronald Pickvance, Van Gogh in Saint-Remy and Auvers (New York: The Metropolitan Museum of Art, 1986),310.

13. Harris JC. Portrait of Dr. Gachet. Arch Gen Psychiatry. 2002;59:1083-4

14. Weatherall DJ, Ledingham JGG, Warrell DA. Oxford Textbook of Medicine. 3rd ed. Oxford: Oxford University Press; 1996. p. 2055.

15. Ramlakhan SL, Fletcher AK. It could have happened to Van Gogh: a case of fatal purple foxglove poisoning and review of the literature. Eur J Emerg Med. 2007;14:356-9.

16. Hammacher, Abraham M. Vincent van Gogh: Genius and Disaster. Harry N. Abrams. Abradale Press, New York. 1985.

17. Marmor MF, Ravin JG. The artist's eyes. New York, NY: Abrams; 2009.

18. Sweetman, David. Van Gogh: His Life and His Art. Touchstone. Crown Publishers, New York. 1990; 342-3. 